\title{
The Mass Assessment Model of Real Estate Based on GIS and VIKOR Method
}

\author{
Xiuli Wang ${ }^{1, ~ a ~}$, Liu Yang ${ }^{2, b}$, Hengkai Li ${ }^{2, c}$ and Jun Lei ${ }^{2, d}$ \\ ${ }^{1}$ College of Economic Management, Jiangxi University of Science and Technology, Ganzhou \\ 341000, China \\ ${ }^{2}$ College of Architecture and Surveying Engineering, Jiangxi University of Science and Technology, \\ Ganzhou 341000, China \\ aitisher@126.com, b gisliusn@126.com, cgiskai@126.com, d2471776198@qq.com
}

Keywords: Real estate valuation, VIKOR, GIS, Model

Abstract. The need for estate mass appraisal imposed by the information-based for the current property tax, estate mass appraisal model what is composed GIS and VIKOR method was proposed. Firstly, house price effect factors were quantified by using GIS spatial analysis methods, secondly, combined with quantitative values, it calculated the price's influence factor of weight with Entropy method. Thirdly, real estate mass appraisal model was built by VIKOR method. Fourth, appropriate real estate valuation system was developed who based on this real estate mass appraisal model. By using this system, five appraisal real estate of Ganzhou were estimated. And the calculated real estate prices are close with the actual trade price. It can be showed that the model had high accuracy, so this model will have a wide range prospect in terms of rapid mass appraisal real estate, and it can provide technical support for the levy of estate duty.

\section{Introduction}

Property tax policy in Shanghai and Chongqing has firstly tried for three years, playing an important role in market regulation has been a growing number of people in the industry consensus[1]. Real estate tax assessment value is more scientific, but mass appraisal on property value needs high technical requirements[2]. Some scholars applied to real estate mass appraisal with smart algorithm such as neural networks and support vector machine, and achieved good results. However, as there are many variables involved in the real estate appraisal, complex variables and price, these intelligent algorithm has a strong data dependent, and assess the accuracy of some volatility[3]. Multiple attribute decision method which is compromise and linear standard (VIKOR) was proposed by Opricovic and Tzeng, which group benefits can be maximized and opposition unfortunately minimized, also can improve the data-dependent problems[4]. In recent years, some scholars had applied geographic information system (GIS) technology in extraction and quantification of house price effect factors[5]. This technology can greatly improve the accuracy of quantification factor. With the combination of GIS technology and theory of VIKOR, blending the advantages of both, a new real estate mass appraisal model and its application is built, which will be able to provide technical support for the real estate tax system reform.

\section{Build Assessment Model}

Establishment of evaluation model is shown in Fig 1. Firstly, to set up a trade case database and an appraised real estate library based on data from trade case and estimated property. Combined with powerful GIS data management capabilities, application input and managed property information. Geospatial location of the trade cases was represented by a point on the map. So the trade case database and appraised real estate library can be set up. Secondly, taking the appraisal real estate as the center, system search around a range of cases. It can find $\mathrm{N}$ comparable trade case by rules which the type property and the property structure of search cases are the same as the real estate. If the screening result is less than n, or you need to expand your search radius to increase trade cases, until the trade case number is over $\mathrm{N}$. Comparable trade case and appraised real estate case are quantified 
by the quantitative rule. The quantitative results are saved to the database. Thirdly, reading the quantitative impact factor values in the database, entropy weight method is used to calculate the price factor weights. While comparable trade case is corrected deal time, and comparable trade cases price of time are modified as the same time of the current estimated property prices. Lastly, correlation coefficient of VIKOR method, such as Hamming distance weighted, weighted Chebyshev distance, and interest rates, are calculated. Based on sorting results which interest rates is sorted from smallest to largest by bubble sort method. So depending on the appraised property sorted result of interest rates, the estimated real estate prices can be calculated by linear interpolation. The critical points of the process are to quantify factors impact on housing prices, calculate weight and construct the VIKOR method of valuation model.

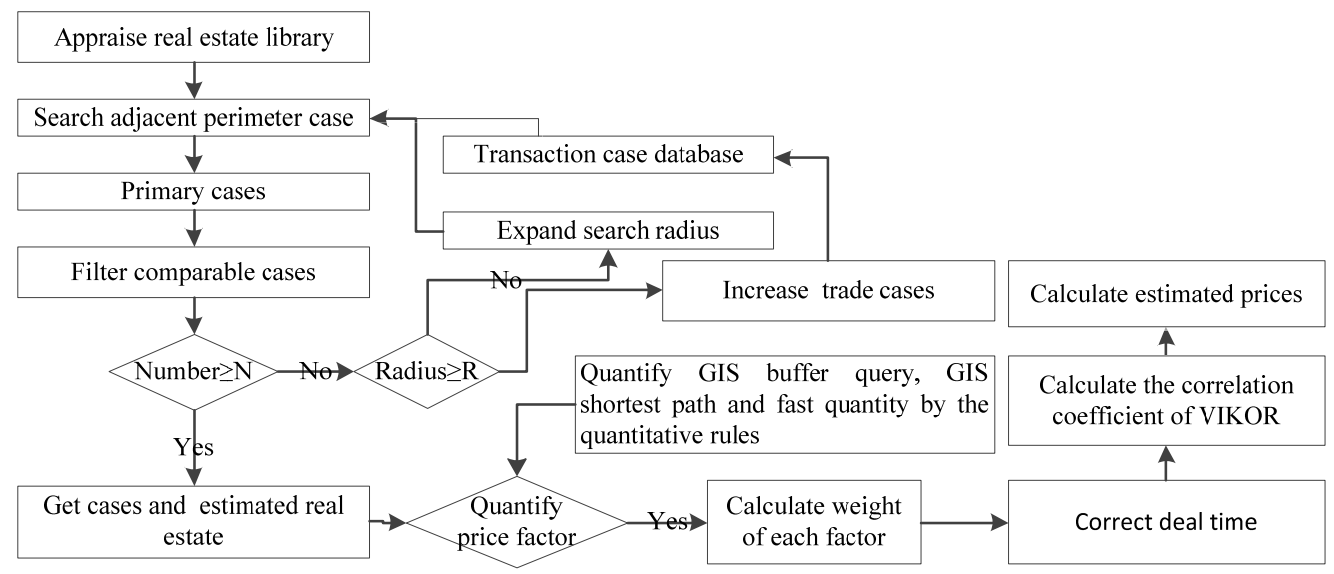

Fig.1 Logic diagram for Evaluation model

Real estate price impact factor and quantitative methods can be sure as table 1.In this table, from P1 to P6 stand impact of location on housing price in real estate area, from P7 to P15 stand impact of housing qualifications on housing price. Using GIS analysis to quantify the real estate, the same factors on different distances have different effect on the housing price. So this model uses a hierarchical buffer query method to quantify. Depending on the degree of setting different values to quantify, quantifiable results can be more objective and reasonable.

Tab.1 Real estate price impact factor and Quantitative methods

\begin{tabular}{|c|c|}
\hline $\begin{array}{l}\text { Housing Price Impact } \\
\text { Factor }\end{array}$ & Quantitative Method of Housing Price Impact Factor \\
\hline $\begin{array}{l}\text { The Distance } \\
\text { To CBD }(P 1)\end{array}$ & $\begin{array}{l}\text { Shortest distances to the city center, } 10 \text { points for } 0 \text { to } 5 \mathrm{~km} ; 8 \text { points for } 5 \text { to } 10 \mathrm{~km} ; 5 \\
\text { points for } 10 \text { kilometers away. }\end{array}$ \\
\hline $\begin{array}{l}\text { Transportation } \\
\text { Convenience }(P 2)\end{array}$ & $\begin{array}{l}\text { Each with } 1 \text { point for bus stations within } 500 \mathrm{~m} \text {;each with } 0.5 \text { point for bus route } \\
\text { through the site; } 2 \text { points for near the main road;each with } 0.6 \text { point for bus stations and bus } \\
\text { routes through the site from } 500 \mathrm{~m} \text { to } 800 \mathrm{~m} \text {,top } 10 \text { points. }\end{array}$ \\
\hline $\begin{array}{c}\text { Supporting } \\
\text { Education }(P 3)\end{array}$ & $\begin{array}{l}3 \text { points for kindergarten within } 600 \mathrm{~m} ; 2 \text { points for primary school and university; } 1 \\
\text { point for kindergarten,primary school,university around the house from } 600 \mathrm{~m} \text { to } 1000 \mathrm{~m} \text {,top } \\
10 \text { points. }\end{array}$ \\
\hline Sports Facility $(P 4)$ & $\begin{array}{l}\text { Each with } 1.5 \text { points for playground,stadium,library and theatre within } 600 \mathrm{~m} \text {; each with } \\
1 \text { point for playground,stadium,library and theatre around the house from } 600 \mathrm{~m} \text { to } 1000 \mathrm{~m} \text {, } \\
\text { top } 10 \text { points. }\end{array}$ \\
\hline Supporting Life ( $P 5)$ & $\begin{array}{l}\text { Each with } 1.2 \text { points for supermarket,bank,shopping mall,hospital,farm within } \\
600 \mathrm{~m} \text {; each with } 0.8 \text { point for supermarket,bank,shopping mall,hospital,farms around the } \\
\text { house from } 600 \mathrm{~m} \text { to } 1000 \mathrm{~m} \text {,top } 10 \text { points. }\end{array}$ \\
\hline $\begin{array}{l}\text { Natural Environment } \\
\qquad(P 6)\end{array}$ & $\begin{array}{l}\text { Each with } 5 \text { points for park and river within } 1000 \mathrm{~m} \text { around the house;reduce each with } \\
1 \text { point for highway, railway, urban main road within } 500 \mathrm{~m} \text {,top } 10 \text { points. }\end{array}$ \\
\hline $\begin{array}{l}\text { Building Facilities } \\
\quad(P 7)\end{array}$ & $\begin{array}{l}\text { Each with } 3 \text { points for water and electricity;each with } 1 \text { point for gas,broadband, } \\
\text { TV,air-conditioning,parking,communications,anti-theft prevention,clean,top } 10 \text { points. }\end{array}$ \\
\hline New Rate $(P 8)$ & $\begin{array}{l}\text { With 8-10 points for good condition;with } 6-8 \text { point for basic good housing; with 4-6 } \\
\text { point for general damage to the housing; under } 4 \text { points for serious damage to the housing } \\
\text { and dangerous rooms. }\end{array}$ \\
\hline Apartment ( $P 9)$ & With 10 points for more than 3 rooms 2 hall and 2 guard;with 8 points for 3 rooms 2 \\
\hline
\end{tabular}




\begin{tabular}{|c|c|}
\hline & $\begin{array}{l}\text { hall and a guard; with } 6 \text { points for } 2 \text { rooms } 2 \text { hall and a guard;with } 4 \text { points for } 2 \text { rooms a hall } \\
\text { and a guard;with } 2 \text { points for others. }\end{array}$ \\
\hline Towards (P10) & $\begin{array}{l}\text { With } 10 \text { points for south;with } 8 \text { points for southeast, southwest, north and south;with } 6 \\
\text { points for east;with } 4 \text { points for west, northeast;with } 2 \text { points for north. }\end{array}$ \\
\hline Floor (P11) & $\begin{array}{l}\text { No elevator: with } 10 \text { points for layer 3; with } 8 \text { points for layer } 4 \text {; with } 6 \text { points for layers } \\
2 \text { and 5; with } 4 \text { points for layer 1; with } 2 \text { points for the top.Elevator: with } 10 \text { points for layers } \\
25 \text { above; with } 8 \text { points for layers } 19 \text { to } 24 \text {; with } 6 \text { points for layers } 13 \text { to } 18 \text {; with } 4 \text { points for } \\
\text { layers } 7 \text { to } 12 \text {; with } 2 \text { points for layers } 1 \text { to } 6 \text {. }\end{array}$ \\
\hline $\begin{array}{l}\text { Community } \\
\text { Environment }(P 12)\end{array}$ & $\begin{array}{l}\text { With } 10 \text { points for optimal: more than } 30 \% \text { green rate,very quiet; with } 8 \text { points for } \\
\text { better: } 20 \% \text { - } 30 \% \text { green rate,quiet; with } 6 \text { points for general: } 15 \%-20 \% \text { green rate, no } \\
\text { noise; with } 4 \text { points for inferior: } 10 \% \text { - } 15 \% \text { green rate, big noise; with } 2 \text { points for bad: less } \\
\text { than } 10 \% \text { green rate, seriously noise.. }\end{array}$ \\
\hline $\begin{array}{c}\text { Property } \\
\text { Management }(P 13)\end{array}$ & $\begin{array}{l}\text { With } 10 \text { points for optimal: first-level management,all day security patrol,video } \\
\text { monitoring.With } 8 \text { points for better: second-level management,all day security patrol,video } \\
\text { monitoring.With } 6 \text { points for general: second-level management,security patrol.With } 4 \\
\text { points for inferior: third-level management.With } 2 \text { points for bad: no management. } \\
\text { With } 10 \text { points for optimal: average } 8 \text { hours sunshine per day,window wall area above }\end{array}$ \\
\hline $\begin{array}{l}\text { Ventilation and } \\
\text { Lighting ( } P 14)\end{array}$ & $\begin{array}{l}\text { 1/3, air convection; with } 8 \text { points for better: average } 6 \text { hours sunshine per day, window wall } \\
\text { area above } 1 / 4 \text {, air convection; with } 6 \text { points for general: average } 5 \text { hours sunshine per } \\
\text { day,window wall area above } 1 / 5 \text {,no air convection; with } 4 \text { points for inferior: average } 2 \\
\text { hours sunshine per day,window wall area above } 1 / 7 \text {, no air convection; with } 2 \text { points for bad: } \\
\text { average below } 2 \text { hours sunshine per day or no window . }\end{array}$ \\
\hline $\begin{array}{l}\text { Repair Situation } \\
\text { (P15) }\end{array}$ & $\begin{array}{l}\text { With 8-10 points for luxury decoration;with 6-8 points for fully decoration;with 4-6 } \\
\text { points for simple decoration;with 2-4 points for no decoration. }\end{array}$ \\
\hline
\end{tabular}

Property influence factors of weight are calculated by objective entropy weight method. The entropy weight of each real estate price effect factor is calculated by entropy, then its for all price factors are weighted. The steps are as follows: Firstly, construct matrix by 15 effect factors quantitative scores of $\mathrm{N}$ comparable trade case. Secondly, calculate proportion $P_{i j}, P_{i j}=p_{i, j} / \sum_{i=1}^{N} p_{i, j}$.Where $p_{i j}$ stands the $\mathrm{j}$-th real estate price effect factor value of the i-th comparable trade case.Thirdly, calculate entropy $E_{j .} E_{j}=(-1 / 1 \mathrm{n} N) \sum_{i=1}^{N} P_{i j} \ln P_{i j}$. Fourth, calculate entropy weight $W_{j}, W_{j}=\left(1-E_{j}\right) / \sum_{j=1}^{15}\left(1-E_{j}\right)$.At last, get a weight vector, $W=\left(W_{1}, W_{2}, \cdots \cdots, W_{15}\right)$.

As the time factor effect on real estate prices, it need correct the trade cases transaction price to the current appraisal real estate prices at the same time. Estimating property price of comparable trade case in the same time calculated by product of chain and comparable trade case price.

Every comparable trade case and appraisal real estate has 15 factors. VIKOR is a method making multiple attribute decision of selecting the best. According to the distance appraisal properties with comparable trade cases as weights, estimating price is interpolated by revised price of comparable trade cases. The steps are as follows: Firstly, construct matrix by appraisal real estate and comparable trade cases. Secondly, matrix is normalized by formula as $f_{i j}=p_{i j} / \operatorname{Max}_{i}\left(p_{i j}\right)$. Where $p_{i j}$ stands the $\mathrm{j}$-th real estate price effect factor value of the $\mathrm{i}$-th comparable trade case. Positive ideal solution and negative ideal solution of appraisal and trading estate effect factors are calculated by new normalized matrix, $f_{i}^{*}=\left(\operatorname{Max}_{i} f_{i j}\right) f_{i}^{-}=\left(\operatorname{Min} f_{i j}\right) \cdot f_{i}^{*}$ and $f_{i}^{-}$stand for positive ideal solution and negative ideal solution. Fourth, hamming weighted distance $S_{i}$ and Chebyshev weighted distance $R_{i}$ of all the appraisal real estate and the trade cases are calculated, $S_{i}=\sum_{j}^{15} W_{j}\left(f_{j}^{*}-f_{i j}\right) /\left(f_{j}^{*}-f_{j}^{-}\right), R_{i}=\operatorname{Max}_{j}\left[W_{j}\left(f_{j}^{*}-f_{i j}\right) /\left(f_{j}^{*}-f_{j}^{-}\right)\right]$. Where $W_{j}$ stands the $\mathrm{j}$-th weight of price effect factor,and the weight is calculated by entropy weight method.Fifth, compute the value $Q, Q_{i}=\frac{V\left(S_{i}-S^{*}\right)}{S^{-}-S^{*}}+(1-v) \frac{\left(R_{i}-R^{*}\right)}{R^{-}-R^{*}}$, where $S^{*}=\operatorname{Min}_{j} S_{j}, S=\operatorname{Max}_{j} S_{j}, R^{*}=\operatorname{Min}_{j} R_{j}, R=$ $\operatorname{Max}_{j} R_{j}, v$ is 0.5 ,stands coefficient of decision mechanism. Appraisal real estate and comparable trade 
cases are sorted by $Q$.At last, appraisal real estate price is interpolated by sorted $Q$ value, $P_{k}^{\prime}=\left[\frac{\left(P_{k+1}^{\prime}-P_{k-1}^{\prime}\right)\left(Q_{k}-Q_{k-1}\right)}{\left(Q_{k+1}-Q_{k-1}\right)}+P_{k-1}^{\prime}\right]$, where $P_{k}^{\prime}$ stands appraisal real estate price, $P^{\prime}{ }_{k+1} 、 P^{\prime}{ }_{k-1}$ stand revised trade case price near this appraisal real estate by sorting $Q_{\text {. }} Q_{k}$ belongs to appraisal real estate, $Q_{k+1}, Q_{k-1}$ belongs to trade cases.

\section{Application}

Combited with above assessment model idea, application was developed by C\# programming language with ArcEngine as GIS software platform.By using this application,five appraisal real estate of Ganzhou were estimated. The steps are as follows: Firstly, information was collected and trade case database and appraisal real estate database were established. While you record, a point was draw in the map that stand the actual location of trade case and appraisal estate, and other basic property information was deposited in corresponding database. Secondly, effect factors of comparable trade case and appraisal estate was quantified as quantitative rule in table 1,and this quantitative results were deposited in database. Thirdly, appraisal real estate price was calculated by VIKOR model. Taking appraisal real estate as center, around its $2 \mathrm{~km}, 5$ comparable trade cases whice are the same estate type and structure and closed transaction time with appraisal estate. Then system quantified effect factors of 5 comparable trade case and appraisal real estate, calculated its weight, adjusted trade time, calculated related parameter of VIKOR, sorted by Q value, interpolated the appraisal real estate. The result present that 5 appraisal real estate prices are above $96 \%$ with the corresponding actual trade case price, and this model has a high accuracy can be proved.

\section{Conclusion}

Combined with advantages of GIS technology and VIKOR theory, this model has high accuracy and efficiency. Using GIS technology in collect data, manage and spatial analyze not only can solve subjective problem caused by experts giving estate price effect factors points, but also infinitely improve quantification accuracy and efficiency of effect factors. On the other hand, VIKOR method can make appraisal estate price more reliable because it solve problem of normal intellectual algorithm depending on large trade cases.so this model will has a wide range prospect in terms of rapid mass appraisal real estate, and it can provide technical support for the levy of estate duty.

\section{Acknowledgements}

This work was financially supported by National Natural Science Foundation project (41261093), Province University students ' innovative projects (201410407048) and Jiangxi University of Science and Technology of University research (HSFJ2014-G01).

\section{References}

[1] PENG Jialiang, GAO Yaqi, HU Jinxing. East China Economic Management, 2015,29 (2):16-21.(In Chinese)

[2] Ziming Zhou. International Taxation In China, 2012,(11):27-31.(In Chinese)

[3] Xu Ge, Zhang Ke. Statistics and Decision, 2014 (17):22-25.(In Chinese)

[4] Opricovic S, Tzeng G H. European Journal of Operational Research, 2007, 178(2): 514-529.

[5] García N, Gámez M, Alfaro E. ANN+ GIS: Neurocomputing, 2008, 71(4): 733-742. 